\title{
Keefektifan Buah Nanas dalam Meningkatkan Haemoglobin pada Wanita Usia Subur dengan Anemia
}

\section{The Effectiveness of Pineapple Increases Hemoglobin in Women Fertile Age with Anemia}

\author{
Mugiati Mugiati $^{1 凶}$, Rosmadewi Rosmadewi ${ }^{1}$ \\ ${ }^{1}$ Poltekkes Tanjungkarang, Indonesia \\ ${ }^{凶}$ Corresponding author e-mail: mugiati1868@gmail.com, Alamat: Jln. Soekarno-Hatta No. 6, Bandar Lampung, \\ Indonesia
}

\begin{tabular}{l}
\hline Article History: \\
Received Mei 2020 \\
Revised Mei 2020 \\
Accepted Juni 2020
\end{tabular}

Keyword:

Anemia; Pineapple; Iron; Women of childbearing age.

Kata kunci:

Anemia; Buah nanas; Zat besi; Wanita usia subur.

\begin{abstract}
s
Background: Women of childbearing age tend to suffer from anemia due to women having menstruation every month and it becomes aggravated if iron intake from daily food is low. Purpose: This study aims to determine the effectiveness of pineapple in the absorption of iron to trigger an increase in hemoglobin levels in female workers of childbearing age. Methods: This study used a quasi-experimental design with a pretest and post-test control group design. The research sample consisted of 90 people who were divided into 3 groups, the first group received $100 \mathrm{mg} /$ day fresh pineapple intake for 30 days and Fe tablets once per week, group 2 got $100 \mathrm{mg} /$ day pineapple intake without Fe tablets, the third group only got $\mathrm{Fe}$ alone. no pineapple added. Data analysis was univariate and bivariate to test the differences in 3 variables using the Independent T-Test statistical test. Results: The results showed that there was an increase in $\mathrm{Hb}$ levels before and after being given $100 \mathrm{gr}$ fresh pineapple fruit and $\mathrm{Fe}$ tablet for 1 month of $0.98 \mathrm{gr} / \mathrm{dl}$. There was a significant effect between before and after giving $100 \mathrm{gr}$ of fresh pineapple fruit and Fe tablets and giving Fe tablets only (pvalue 0.047). Conclusion: The consumption of pineapple in women of childbearing age and Fe tablets can increase hemoglobin levels when consumed regularly and regularly at a minimum dose of $100 \mathrm{~g} /$ day. Pineapple can be selected as a daily fruit intake to increase iron absorption.
\end{abstract}

\begin{abstract}
Abstrak
Latar Belakang: Wanita usia subur cenderung menderita anemia disebabkan wanita mengalami menstruasi setiap bulan dan menjadi diperberat jika asupan zat besi dari makanan sehari-hari rendah. Tujuan: Penelitian ini bertujuan mengetahui efektifitas buah nanas dalam penyerapan zat besi guna memicu kenaikan kadar haemoglobin pada pekerja wanita usia subur. Metode: Penelitian ini menggunakan desain quasi eksperimental dengan pre test and post test control group design. Sampel penelitian berjumlah 90 orang yang dibagi menjadi 3 kelompok, kelompok pertama mendapat asupan nanas segar $100 \mathrm{mg} / \mathrm{hr}$ selama 30 hari dan tablet Fe 1x/pekan, kelompok 2 mendapat asupan nanas $100 \mathrm{mg} / \mathrm{hr}$ tanpa tablet $\mathrm{Fe}$, kelompok ketiga hanya mendapat Fe saja tanpa tambahan nanas. Analisis data secara univariat dan bivariat untuk menguji perbedaan 3 variabel dengan menggunakan uji statistic Independent T-Test. Hasil: Hasil penelitian menunjukkan bahwa terdapat peningkatan kadar Hb sebelum dan sesudah diberikan buah nanas segar 100 gr dan tablet Fe selama 1 bulan sebesar $0,98 \mathrm{gr} / \mathrm{dl}$. Ada pengaruh yang signifikan antara sebelum dan sesudah pemberian buah nanas segar $100 \mathrm{gr}$ dan tablet $\mathrm{Fe}$ maupun pemberian tablet $\mathrm{Fe}$ saja ( $p$-value 0,047). Simpulan: Konsumsi buah nanas pada wanita usia subur dan tablet $\mathrm{Fe}$ mampu peningkatan kadar haemoglobin bila dikonsumsi rutin dan teratur minimal dengan dosis 100 gr/hari. Nanas dapat dipilih sebagai asupan buah sehari-hari dalam meningkatkan absorbsi zat Fe. Anemia; Buah nanas; Zat besi; Wanita usia subur.
\end{abstract}

Copyright ( 2020 Jurnal Kesehatan Metro Sai Wawai. All rights reserved.

\section{Pendahuluan}

Wanita usia subur cenderung menderita anemia dikarenakan wanita mengalami menstruasi setiap bulan, dan ini akan diperberat jika asupan zat besi dari makanan sehari-hari rendah. Wanita usia 
subur yang mengalami anemia gizi besi akan mudah sakit karena daya tahan tubuh yang rendah, sehingga produktivitas kerja rendah (Kemkes RI, 2014). Produktivitas kerja pada wanita juga dapat dipengaruhi oleh status anemia. Adapun tingkat partisipasi angkatan Kerja (TPAK) pekerja perempuan semakin meningkat dari 52,71\% pada bulan Februari 2016 naik menjadi 55,04\% di bulan Februari 2017, lebih dari 30\% wanita bekerja pada sektor pertanian dan agroindustri (BPS, 2017).

Prevalensi anemia diperkirakan 9\% di negara-negara maju, sedangkan di negara berkembang prevalensi anemia 43\%. Anak-anak dan wanita usia subur (WUS) adalah kelompok yang paling berisiko, dengan perkiraan prevalensi anemia pada balita sebesar 47 persen, pada wanita hamil sebesar 42 persen, dan pada wanita yang tidak hamil usia 15-49 tahun sebesar 30\%. World Health Organization (WHO) menargetkan penurunan prevalensi anemia pada WUS berjumlah $50 \%$ pada tahun 2025 (WHO, 2011).

Sementara di Indonesia berdasarkan hasil Riskesdas tahun 2013 menunjukkan prevalensi anemia pada WUS umur 15-44 tahun sebesar 35,3\% (Kemkes RI, 2013). Di Provinsi Lampung pada tahun 2018 terdapat prevalensi anemia sebanyak 11,57\% yang tersebar di 16 kabupaten/ kota. Angka kejadian anemia di Lampung Tengah terdapat 7,70\%. Keadaan anemia ini dapat diicegah secara farmakologis dengan pemberian tablet tambah darah (TTD) yang pedomannya sudah diatur dalam Peraturan Menteri Kesehatan. Selain tablet tambah darah, pencegahan anemia juga dapat dilakukan secara non farmakologis, yaitu dengan asupan makanan dan buah- buahan yang mengandung zat besi dan vitamin $\mathrm{C}$ yang tinggi, misalnya mengkonsumsi buah nanas.

Nanas (Ananas comosus L.) merupakan tanaman yang diperkirakan berasal dari Amerika Selatan yang ditemukan oleh orang Eropa pada tahun 1493 di pulau Caribean. Akhir abad ke-16 Portugis dan Spanyol memperkenalkan nanas ke benua Asia, Afrika, dan Pasifik Selatan, sehingga pada abad ke-18, buah ini dibudidayakan di Hawaii, Thailand, Filipina, China, Brasil, dan Meksiko (Lawal, 2013).

Nanas (ananas) termasuk kedalam famili Bromeliaceae adalah salah satu buah yang dapat meningkatkan penyerapan zat besi dalam usus. Buah nanas adalah buah yang memiliki rasa manis dan sedikit asam. Kandungan gizi dari nanas antara lain, vitamin C 79\%, vitamin B6 5\%, vitamin A 1\%, besi $1 \%$, magnesium $3 \%$, folat dan zat lainnya yang bermanfaat bagi tubuh. Selain gizi tersebut, manfaat buah nanas juga baik untuk kesehatan tubuh secara keseluruhan. Manfaat buah nanas juga dapat mencegah penggumpalan darah. Nanas memiliki peran dalam memproduksi hemoglobin di dalam tubuh. Jika tubuh mengalami kekurangan zat ini maka bisa menyebabkan anemia, penurunan kadar sel darah putih, masalah tiroid, dan osteoporosis (Darawati, 2016).

Hasil penelitian beberapa literatur menunjukkan hasil yang kontradiktif. Penelitian oleh Kamalia, Sulistyaningsih, \& Sugiyanta (2014) menggunakan desain eksperimen murni secara in vivo dengan rancangan randomized pre and post test controlled group design dilakukan di laboratorium dan Sampel penelitian adalah tikus strain wistar jantan usia 2 bulan dengan berat rata-rata 100 gram dengan intervensi pemberian dosis ekstrak nanas sebesar 7,9 dan $11 \mathrm{mg} /$ hari menghasilkan peningkatan kadar hemoglobin. Sedangkan, Maisaroh (2019) dalam penelitian dengan intervensi kombinasi jus bayam dengan nanas tidak dapat meningkatkan kadar hemoglobin pada tikus anemia.

Penelitian ini dilakukan untuk melihat keefektifan buah nanas dalam membantu meningkatkan kadar Haemoglobin pada wanita usia subur. Subyek penelitian yang diambil wanita usia subur yang dibagi menjadi tiga kelompok intervensi dan buah nanas yang diberikan kuantitasnya lebih banyak dibandingkan penelitian sebelumnya. Manfaat yang diharapkan buah nanas menjadi bagian konsumis masyarakat khususnya WUS untuk mempertahankan ataupun meningkatkan kadar haemoglobin. 


\section{Metode}

Penelitian ini menggunakan metode penelitian kuantitatif (analitik) dengan menggunakan desain quasi eksperimental dengan pre test and post test control group design Lokasi penelitian dilakukan di salah satu perusahaan agro industri yang berada di kabupaten Lampung Tengah Provinsi Lampung. Sampel adalah karyawan perempuan di perusahaan tersebut berjumlah 90 orang yang terdiri atas kelompok intervensi 1, intervensi 2 dan intervensi 3 masing-masing berjumlah 30 responden. Pengambilan sampel menggunakan teknik accidental sampling yang memenuhi syarat penelitian. Kriteria inklusi sampel adalah perempuan usia 20 - 40 tahun, tidak mempunyai penyakit berat seperti TBC dan anemia berat dan kelainan dan mengikuti protokol penelitian sampai selesai.

Prosedur intervensi dilakukan dengan langkah-langkah: (1) Setelah memperoleh inform consent dari respondent yang memenuhi kriteria sampel, membagi Responden menjadi 3 kelompok intervensi, yaitu kelompok intervensi 1, kelompok intervensi 2 dan kelompok intervensi 3; (2) melakukan pengukuran kadar Haemoglobin Responden sebelum perlakuan; (3) memberikan perlakuan kepada kepada masing-masing kelompok perlakuan sesuai SOP penelitian selama 30 hari, yaitu kelompok intervensi 1 diberikan diberikan 1 potong nanas segar 100 gram setiap hari dan diberikan 1 tablet $\mathrm{Fe}$ setiap akhir pekan, kelompok intervensi 2 diberikan diberikan 1 potong nanas segar 100 gram setiap hari, dan kelompok intervensi 3 diberikan tablet Fe setiap satu pekan sekali selama 4 kali atau satu bulan; (4) Memantau pemberian buah nanas yang diberikan saat jam istirahat; (5) Melakukan pengukuran kadar Haemoglobin setiap kelompok perlakuan setelah 30 hari. Pelaksanaan prosedur intervensi dibantu oleh enumerator (asisten peneliti lapangan). Validitas data dan meminimalkan bias ekperimen, terlebih dahulu dilakukan persamaan persepsi dengan enumerator yang secara langsung memberikan bahan (nanas dan tablet $\mathrm{Fe}$ ) intervensi kepada setiap kelompok intervensi.

Analisis data menggunakan independent t-test untuk menguji rerata perbedaan antar grup $\geq 2$ variabel. Sebelum dimulai eksperimen penelitian telah dilakukan kaji etik. Penelitian ini memenuhi kaji etik oleh Komisi Etik penelitian kesehatan Poltekkes Tanjungkarang dengan nomor 240/EA/KEPK-TJK/VIII/2019 tanggal 20 Agustus 2019.

\section{Hasil}

\section{Karakteristik responden}

Tabel 1 menggambarkan responden yang berusia 20-30 tahun sebanyak 22 orang (32,2\%), usia 31- 40 tahun sebanyak 61 orang $(67,8 \%)$. Responden dengan jenjang pendidikan SMP sebanyak 34 orang (37,8\%), SMA sebanyak 56 orang $(62,2 \%)$. Responden dengan IMT $\leq 18,4$ terdapat 13 orang $(14,4 \%)$, IMT antara 18,5-24,9 terdapat 45 orang (50,0\%), IMT antara 25,0-29,9 terdapat 27 orang $(30,0 \%)$, dan 5 orang $(5,6 \%)$ dengan IMT antara 30,0-39,9.

\section{Peningkatan kadar Hb setelah diberikan intervensi buah nanas dan tablet $\mathrm{Fe}$}

Hasil analisis pada tabel 3 menggambarkan peningkatan kadar $\mathrm{Hb}$ setelah diberikan intervensi. Responden pada kelompok intervensi 1, 2 dan 3 masing-masing terjadi peningkatan kadar $\mathrm{Hb} 0,87$ gr\%, 0,71gr\% dan 0,20 gr\%. Gambar 1 menggambarkan perubahan kadar haemoglobin pada kelompok intervensi 1 sebelum intervensi ( $\mathrm{Hb} 1)$ dan sesudah intervensi $(\mathrm{Hb}$ 2) diperoleh 18 dari 30 orang $(60 \%)$ saat dilakukan pemeriksaan kadar $\mathrm{Hb}$ setelah intervensi mengalami kenaikan. Kadar haemoglobin pada kelompok intervensi 2 menunjukkan hanya 9 (30\%) dari 30 responden mengalami peningkatan (Gambar 2). Sedangkan, pada kelompok intervensi 3 diperoleh gambaran kadar haemoglobin responden sebelum intervensi $(\mathrm{Hb}$ 1) dan setelah intervensi ( $\mathrm{Hb}$ 2) terdapat 25 dari 30 orang $(83.3 \%)$ saat dilakukan pemeriksaan kadar $\mathrm{Hb}$ mengalami kenaikan (Gambar 3). 


\section{Hasil uji normalitas data sebelum dan sesudah intervensi}

Hasil uji pada tabel 3 menunjukkan bahwa tingkat pengujian normalitas kolmogorov-smirnov selisih kadar $\mathrm{Hb}$ sebelum diberikan nanas segar dan tablet Fe dengan sebelum pemberian tablet Fe saja sebesar 0,139: 0,063 gr\%, selisih kadar $\mathrm{Hb}$ setelah pemberian nanas segar dan tablet $\mathrm{Fe}$ dengan pemberian tablet Fe saja 0,200:0,200 gr\%. Hasil pengujian shapiro-wilk selisih kadar Hb sebelum diberikan nanas segar dan tablet Fe dengan sebelum pemberian tablet Fe saja sebesar 0,09: 0,92 gr\%, serta selisih kadar $\mathrm{Hb}$ setelah pemberian nanas segar dan tablet $\mathrm{Fe}$ dengan pemberian tablet $\mathrm{Fe}$ saja adalah $0,276: 0,639 \mathrm{gr} \%$.

Tabel 1.

Gambaran karakteristik responden

\begin{tabular}{|c|c|c|c|c|}
\hline Karakteristik Responden & \multicolumn{2}{|l|}{ Kategori } & $f=90$ & Jumlah (n=100) \\
\hline \multirow[t]{3}{*}{ Umur responden } & \multicolumn{2}{|c|}{ 20-30 tahun } & 22 & $24,4 \%$ \\
\hline & \multicolumn{2}{|c|}{ 31-40 tahun } & 61 & $67,8 \%$ \\
\hline & \multicolumn{2}{|c|}{ 41-50 tahun } & 7 & $7,8 \%$ \\
\hline \multirow[t]{2}{*}{ Pendidikan } & \multicolumn{2}{|l|}{ SMP } & 34 & $37,8 \%$ \\
\hline & \multicolumn{2}{|l|}{ SMA } & 56 & $62,2 \%$ \\
\hline \multirow[t]{4}{*}{ IMT } & $\leq 18,4$ & (BB kurang) & 13 & $14,4 \%$ \\
\hline & $18,5-24,9$ & (BB ideal) & 45 & $50,0 \%$ \\
\hline & $25-29,9$ & (BB lebih) & 27 & $30,0 \%$ \\
\hline & $30-39,9$ & (Gemuk) & 5 & $5,6 \%$ \\
\hline
\end{tabular}

Konsumsi Nanas dan Tablet Besi

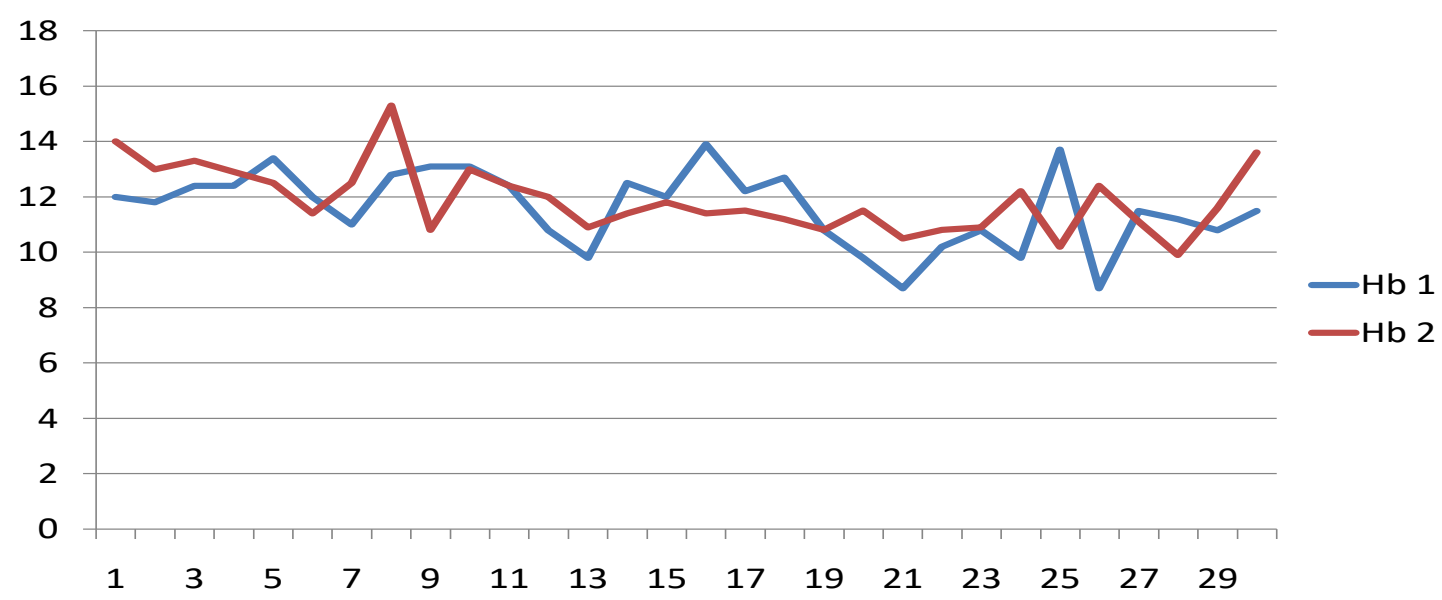

Gambar 1.

Grafik kadar Hb Sebelum dan sesudah diberikan intervensi buah nanas dan tablet besi 


\section{Konsumsi Nanas}

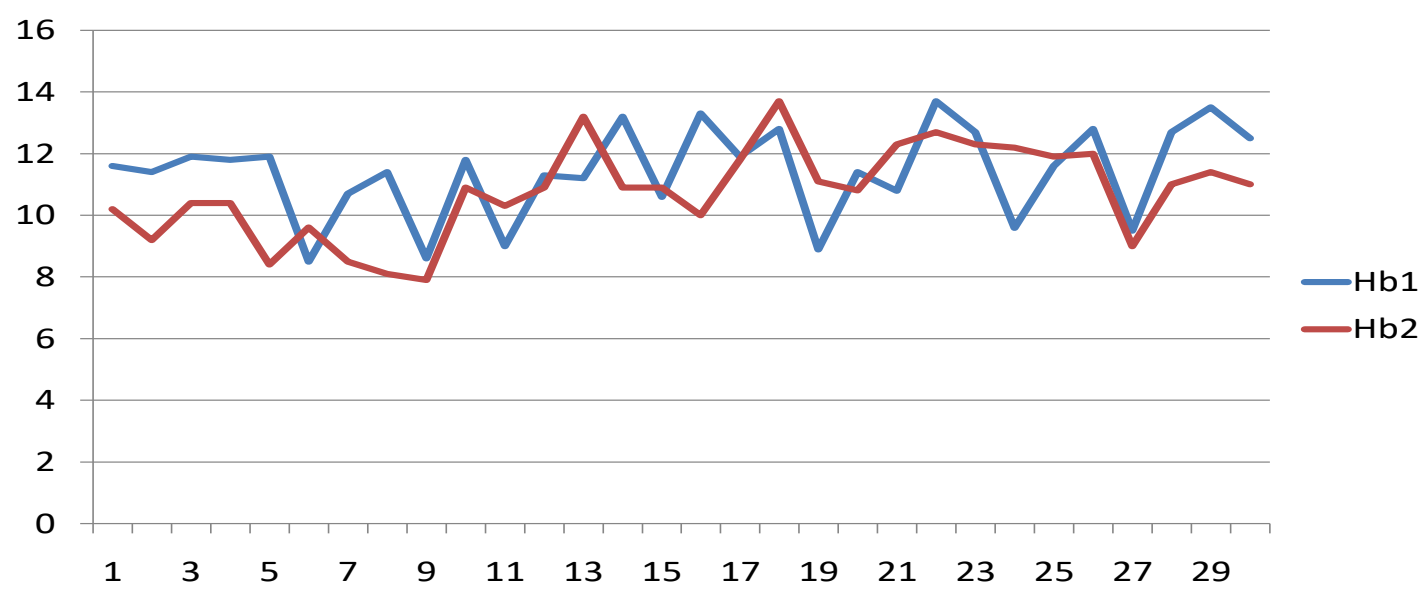

Gambar 2.

Grafik kadar Hb kelompok intervensi 2 sebelum dan sesudah diberikan intervensi buah Nanas

Konsumsi tablet besi

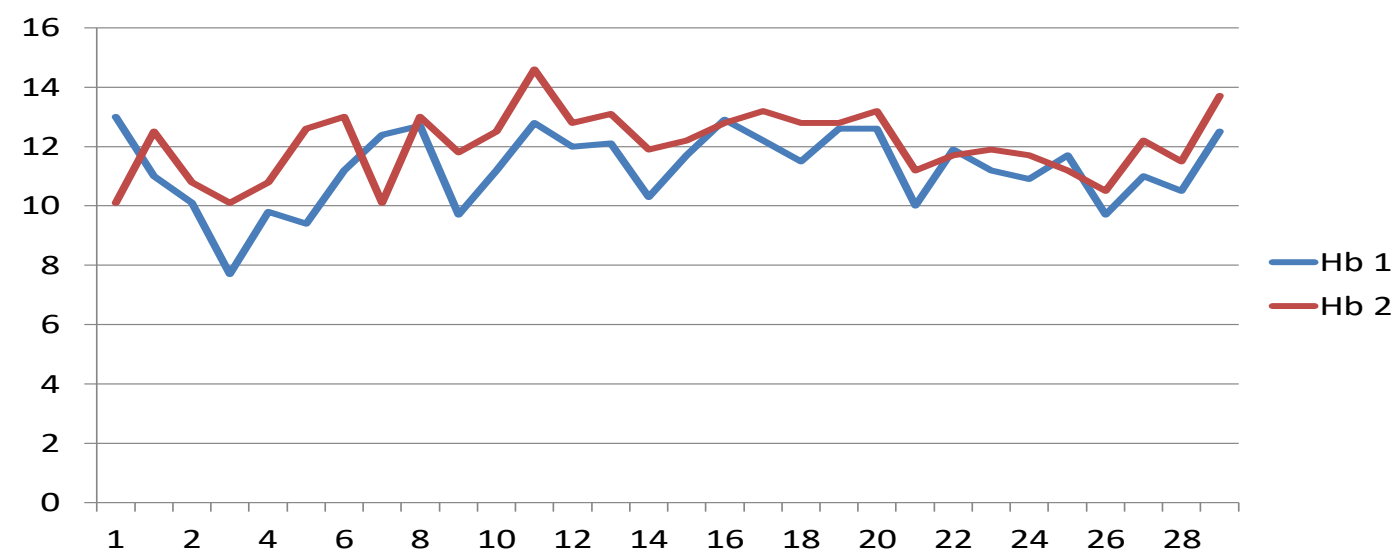

Gambar 3. Grafik kadar Hb kelompok intervensi 3 sebelum dan sesudah diberikan suplemen tablet Fe

Tabel 3.

Uji normalitas selisih sebelum dan sesudah pemberian buah nanas segar dan Fe dan tablet Fe terhadap efektifitas penyerapan kadar $\mathrm{Hb}$

\begin{tabular}{llllllll}
\hline \multirow{2}{*}{ Intervensi } & & \multicolumn{3}{l}{ Kolmogorov-Smirnov } & \multicolumn{3}{l}{ Shapiro-Wilk } \\
\cline { 3 - 7 } & & Statistic & Df & Sig. & statistic & Df & Sig \\
\hline $\mathrm{Hb} 1$ & Diberikan nanas segar dan tablet Fe & 155 & 30 & 0.139 & 0,901 & 30 & 0.09 \\
& Diberikan Fe & 140 & 30 & 0.063 & 0.940 & 30 & 0.92 \\
$\mathrm{Hb} 2$ & Diberikan nanas segar dan tablet Fe & 102 & 30 & 0.200 & 0.958 & 30 & 0.276 \\
& Diberikan tablet Fe & 107 & 30 & 0.200 & 0.974 & 30 & 0.639 \\
\hline
\end{tabular}


Tabel 4.

Hasil independent t-test kadar $\mathrm{Hb}$ sebelum dan sesudah pemberian buah nanas segar ditambah tablet Fe dan pemberian tablet Fe saja

\begin{tabular}{llllll}
\hline Intervensi & & Levene's Test (Sig.) & n & Mean \pm SD & Sig. (2-tailed) \\
\hline Selisih & $\begin{array}{l}\text { Pemberian nanas segar dan } \\
\text { tablet Fe }\end{array}$ & 0,413 & 30 & $0,977 \pm 0.6527$ & 0,047 \\
& \begin{tabular}{l} 
Pemberian tablet Fe saja \\
\cline { 2 - 5 }
\end{tabular} & & 30 & $0,677 \pm 0.4768$ & 0,047 \\
\hline
\end{tabular}

\section{Pembahasan}

Wanita usia subur cenderung menderita anemia disebabkan wanita mengalami menstruasi setiap bulan (Kemkes RI, 2014). Hasil penelitian menunjukkan bahwa terdapat peningkatan kadar $\mathrm{Hb}$ sebelum dan sesudah diberikan buah nanas segar 100 gr dan tablet Fe selama 1 bulan sebesar 0,98 $\mathrm{gr} / \mathrm{dl}$. Ada pengaruh yang signifikan antara sebelum dan sesudah pemberian buah nanas segar $100 \mathrm{gr}$ dan tablet $\mathrm{Fe}$ maupun pemberian tablet Fe saja ( $p$-value 0,047 ).

Salah satu buah yang bermanfaat untuk meningkatkan $\mathrm{Hb}$ adalah mengkonsumsi buah nanas, selain asupan tablet Fe pada wanita. Nanas merupakan salah satu buah yang mengandung vitamin $\mathrm{C}$ dan dapat membantu meningkatkan kadar hemoglobin (Almatsier, 2012). Menurut Jatmiko (2020) buah nanas merupakan sumber fitokimia termasuk bioflavonoid dan tannin, juga sangat kaya akan anti oksidan yang dikenal sebagai flavonoid dan asam fenolik (Jatmiko, 2020).

Nanas (ananas) termasuk kedalam famili Bromeliaceae adalah salah satu buah yang dapat meningkatkan penyerapan zat besi dalam usus. Buah nanas adalah buah yang memiliki rasa manis dan sedikit asam. Kandungan gizi dari nanas antara lain, vitamin C 79\%, vitamin B6 5\%, vitamin A 1\%, besi $1 \%$, magnesium 3\%, folat dan zat lainnya yang bermanfaat bagi tubuh. Selain gizi tersebut, manfaat buah nanas juga baik untuk kesehatan tubuh secara keseluruhan. Manfaat buah nanas juga dapat mencegah penggumpalan darah. Nanas memiliki peran dalam memproduksi hemoglobin di dalam tubuh. Jika tubuh mengalami kekurangan zat ini maka bisa menyebabkan anemia, penurunan kadar sel darah putih, masalah tiroid, dan osteoporosis (Darawati, 2016).

Kadar Haemoglobin merupakan factor yang penting dan berhubunagn dengan produktivitas kerja, sebagaimana penelitian yang dilakukan oleh Suci Widiastuti dan Fillah (2016) menyebutkan bahawa terdapat hubungan antara asupan energy, persentasi lemak tubuh, IMT dan Kadar haemoglobin dengan produktivitas kerja, Variabel yang paling berhubungan dengan produktivitas kerja pada pekerja wanita adalah kadar haemoglobin dengan R2 = 0,348 (Widiastuti \& Dieny, 2016).

Penelitian yang dilakukan di perusahaan agroindustri ini memilih pekerja wanita sebagai sampelnya karena 60\% dari pekerja di perusahaan ini adalah wanita, sebagaimana hasil penelitian Widiastuti bahwa produktivitas kerja ditentukan juga oleh kondisi kadar haemoglobin pekerja tersebut. Hasil didapatkan rata-rata kadar $\mathrm{Hb}$ pada sebelum dan sesudah diberikan buah nanas dan tablet $\mathrm{Fe}$ mengalami kenaikan dari 11,557 menjadi 12,543. Klasifikasi kadar Hb sebelum diberikan buah nanas dan tablet fe dengan anemia ringan 9 dan sedang 9 orang. Setelah diberikan buah nanas dan tablet fe klasifikasi anemia ringan menjadi 4 orang dan anemia sedang berkurang menjadi 2 orang.

Pada responden yang diberikan buah nanas saja didapatkan rata-rata kadar Hemoglobin mengalami kenaikan yaitu dari 11,047 sebelum mengkonsumsi nanas menjadi 11,247. Dimana klasifikasi dengan anemia ringan sebelum diberikan buah nanas terdapat 15 orang, anemia sedang 10 orang dan setelah diberikan buah nanas klasifikasi anemia ringan berkurang menjadi 4 orang Hasil didapatkan rata-rata kadar $\mathrm{Hb}$ pada sebelum dan sesudah diberikan tablet fe mengalami kenaikan dari 11,630 menjadi 12,343. Dimana kasifikasi Hb sebelum diberikan tablet fe dengan anemia ringan 11 orang dan anemia sedang 7 orang. Setelah diberikan tablet fe setiap 1 minggu sekali anemia ringan menjadi 10 orang. Pada penelitian ini kenaikan kadar $\mathrm{Hb}$ yang paling efektif adalah dengan 
diberikannya buah nanas segar 100 gr ditambah tablet Fe yaitu dengan rata-rata kenaikan dari 11,557 menjadi 12,543, dibandingkan dengan rata-rata kenaikan kadar $\mathrm{Hb}$ pada pemberian tablet fe saja yaitu dari 11,630 menjadi 12,343. Penelitian yang dilakukan Guntur (2004) mengatakan bahwa konsumsi besi memberikan bentuk hubungan positif dengan kadar hemoglobin dimana ada kecenderungan semakin tinggi konsumsi besi semakin tinggi kadar hemoglobin dan konsumsi vitamin $\mathrm{C}$ dapat berperan meningkatkan absorbsi zat besi non home menjadi 4 kali.

Hasil penelitian ini menguatkan hasil penelitian Kamalia, Sulistyaningsih \& Sugiyanta (2014) yang dilakukan secara in vivo menggunakan desain eksperimen murni dengan rancangan randomized pre and post test controlled group design dilakukan di laboratorium dan Sampel penelitian adalah tikus strain wistar jantan usia 2 bulan dengan berat rata-rata 100 gram dengan intervensi pemberian dosis ekstrak nanas sebesar 7, 9 dan $11 \mathrm{mg} /$ hari menghasilkan peningkatan kadar hemoglobin. Hasil lain dari penelitian ini berdasarkan analisis univariat terlihat bahwa responden yang hanya di beri buah nanas saja hanya 9 orang yang kadar $\mathrm{Hb}$ nya mengalami kenaikan setelah pengujian hari ke-30, hal ini menjadi kelemahan dalam penelitian ini dimana nilai ke efektifan buah nanas sangat rendah untuk dapat diterapkan pada wanita yang menderita anemia. Murniati (2010) menejlaskan bahwa buah nanas mempunyai berbagai macam kandungan gizi yaitu protein, lemak, karbohidrat, fosfor, kalori, zat besi, vitamin (A, B). Selain itu terdapat juga kandungan magnesium, kalsium, natrium, vitamin (C, B2), kalium, sukrosa (gula tebu). Unsur dalam vitamin $C$ inilah yang membantu dalam penyerapan zat besi yang diberikan bersamaan dengan pemberian tablet Fe, sedangkan jika pemberian nanas saja terdapat hambatan dalam peningkatan kadar haemoglobin. Perlu adanya penelitian lebih lanjut untuk mengkaji zat penghambat yang terkandung dalam buah nanas. Namun demikian, konsumsi buah nanas dalam implikasi peningkatan haemoglobin pada wanita usia subur dapat diterapkan di masyarakat baik yang mengalami anaemia maupun untuk mencegah anemia.

\section{Simpulan dan Saran}

Pemberian buah nanas pada wanita usia subur dan tablet Fe mampu peningkatan kadar haemoglobin bila dikonsumsi rutin dan teratur minimal dengan dosis $100 \mathrm{gr} / \mathrm{hari}$. Wanita usia subur yang setiap bulan mengalami menstruasi dapat memanfaatkan buah nanas untuk mencegah anemia. Perlu penelitian lebih lanjut dengan desain randomized controlled trial untuk memperoleh hasil penelitian gold.

\section{Ucapan terimakasih}

Terima kasih kepada Badan PPSDMK yang telah mendanai penelitian ini dan Direksi GGPC Lampung Tengah beserta staf yang banyak membantu peneliti selama melakukan riset di lapangan.

\section{Referensi}

Almatsier, S. (2012). Prinsip dasar ilmu gizi. Jakarta: Gramedia Pustaka Utama.

Badan Pusat Statistik. (2017). Survei angkatan kerja nasional. Retrieved from https://sirusa.bps.go.id/index.php?r=sd/view\&kd=5\&th=2017

Darawati, M. (2016). Ilmu gizi teori dan aplikasi (Hadinsyah (Ed.). Jakarta: Penerbit EGC.

Guntur. (2004). Vitamin C sebagai faktor domain untuk kadar hemoglobin pada wanita usia 20-35 tahun. Jurnal Kedokteran Trisakti Volume 23.

Indriyani, Y., Khomsan, A., Sukandar, D., Riyadi, D., \& Zuraida, R. (2013). Pengaruh pemberian zat besi dan asam folat dengan multivitamin dan mineral pada pekerja wanita usia subur di Agroindustri Nanas. Makara Seri Kesehatan. 17(1). 17-25. Retrieved from http://repository.lppm.unila.ac.id/id/eprint/111 
Jatmiko, N. D. (2020). Bromelain di temukan di batang buah nanas. https://ringtimesbanyuwangi.pikiranrakyat.com/gaya-hidup/pr-17374442/bromelain-di-temukan-di-batang-buah-nanas

Kamalia, A., Sulistyaningsih, E. \& Sugiyanta (2014). Terapi Nutritif Modifikasi Modisco Menggunakan Ekstrak Nanas Meningkatkan Hemoglobin pada Tikus Wistar KEP Berat. E-Jurnal Pustaka Kesehatan. 2(1), 1722. Retrieved from http://jurnal.unej.ac.id/index.php/JPK/article/view/591

Kemkes RI. (2014). PMK No.88 ttg Standar Pemberian Tablet Tambah Darah bagi WUS dan Ibu Hamil. Jakarta: Kemkes RI.

Kemkes RI, Badan Litbangdepkes. (2013). Riset Kesehatan Dasar (Riskesdas) Tahun 2013. Jakarta : Badan Litbangdepkes RI.

Lawal, D. (2013). Medicinal, Pharmacological And Phytochemical Potentials Of Annona Comsus Linn. Peel-A Review. Bayero Journal Of Pure And Applied Sciences. 6 (1): 101-104. DOI: 10.4314/bajopas.v6i1.21

Maisaroh, A. (2019). Intervensi Jus Bayam dengan Nanas terhadap Kadar Hemoglobin Tikus Wistar Anemia. Prosiding Seminar Nasional INAHCO, $\quad 1 . \quad$ Retrieved from https://publikasi.polije.ac.id/index.php/inahco/article/view/1784/0

Murniati. (2010). Sang nanas bersisik manis di lidah. Surabaya: Penerbit SIC

WHO. (2011). Haemoglobin Concentrations for the Diagnosis of Anaemia and Assessment of Severity. Geneva. Retreived from https://apps.who.int/iris/bitstream/handle/10665/85839/WHO_NMH_NHD_MNM_11.1_eng.pdf?ua=1

Widiastuti, S., \& Dieny, F. F. (2016). Faktor determinan produktivitas kerja pada pekerja wanita. Jurnal Gizi Indonesia. 4(1), 28-37. DOI: https://doi.org/10.14710/jgi.4.1.28-37

Sitasi: $\quad$ Mugiati \& Rosmadewi. (2020). Keefektifan Buah Nanas dalam Meningkatkan Haemoglobin pada Wanita Usia Subur dengan Anemia. Jurnal Kesehatan Metro Sai Wawai. 13(1). 36-43. DOI: http://dx.doi.org/10.26630/jkm.v13i1.2162

Hiperlink DOI: http://dx.doi.org/10.26630/jkm.v13i1.2162 